\title{
Enterobacter cloacae, an Emerging Plant-Pathogenic Bacterium Affecting Chili Pepper Seedlings
}

\author{
Tanahiri García-González ${ }^{1}$, Hilda Karina Sáenz-Hidalgo ${ }^{1}$, Hilda Victoria Silva-Rojas ${ }^{2}$, Carlos Morales-Nieto ${ }^{3}$, \\ Taca Vancheva ${ }^{4}$, Ralf Koebnik ${ }^{4}$, and Graciela Dolores Ávila-Quezada ${ }^{3 *}$ \\ ${ }^{1}$ Universidad Autónoma de Chihuahua, Chihuahua, Campus 1, Av. Universidad s/n, 31500 Chihuahua, México \\ ${ }^{2}$ Colegio de Postgraduados, Campus Montecillo, Km. 36.5 Carretera México-Texcoco, 56230 Estado de México, México \\ ${ }^{3}$ Universidad Autónoma de Chihuahua, Facultad de Zootecnia y Ecología, Periférico Francisco R. Almada Km 1, \\ Chihuahua 31453 Chihuahua, México \\ ${ }^{4} U M R$ Interactions Plantes Microorganismes Environnement (IPME), IRD-Cirad-Université Montpellier, 911 Avenue \\ Agropolis, 34394 Montpellier, France
}

(Received on June 25, 2017; Revised on September 24, 2017; Accepted on October 13, 2017)

A previously unreported bacterial disease on chili pepper (Capsicum annuum L.) seedlings affecting as many as $4 \%$ of seedlings was observed in greenhouses in Chihuahua, Mexico (Delicias and Meoqui counties). Initial lesions appeared as irregular small spots on leaves and brown necrosis at margins tips were observed. Later, the spots became necrotic with a chlorotic halo. Advanced disease was associated with defoliation. A Gram negative, rod-shaped bacterium was isolated from diseased chili pepper seedlings. Three inoculation methods revealed that isolated strains produce foliage symptoms, similar to those observed in naturally infected seedlings. Pathogenic strains that caused symptoms in inoculated seedlings were re-isolated and identified to fulfill koch's postulate. Polyphasic approaches for identification including biochemical assays (API 20E and $50 \mathrm{CH}$ ), carbon source utilization profiling (Biolog) and 16S rDNA, hsp60 and rpoB sequence analysis were done. Enterobacter cloacae was identified as the causal agent of this outbreak on chili pepper seedlings.

Keywords : bacterium, Capsicum annuиm L., hsp60, rpoB, $16 \mathrm{~S}$ rDNA

\footnotetext{
*Corresponding author.

Phone) +52-6144340363, FAX) +52-6144340363

E-mail)gavilaq@gmail.com

(c) This is an Open Access article distributed under the terms of the Creative Commons Attribution Non-Commercial License (http:// creativecommons.org/licenses/by-nc/4.0) which permits unrestricted noncommercial use, distribution, and reproduction in any medium, provided the original work is properly cited.
}

Articles can be freely viewed online at www.ppjonline.org.
Handling Associate Editor : Oh, Chang-Sik

Enterobacter cloacae is a ubiquitous Gram-negative, facultative anaerobic, rod-shaped bacterium belonging to the Enterobacteriaceae family. E. cloacae is found as a commensal in the gut flora of many humans and animals (Fanaro et al., 2003). Under certain conditions, E. cloacae can lead to infections of the urinary or respiratory tract or of the bloodstream (Mezzatesta et al., 2012). As an occasional contaminant of medical devices and solutions, E. cloacae has been linked to nosocomial outbreaks, which are of particular concern in neonatal units (Dalben et al., 2008). Moreover, frequent isolation of multidrug-resistant strains is going to confront antibiotic treatment of patients and silver sterilization of wounds and medical devices (DavinRegli and Pagès, 2015).

More recently, E. cloacae has increasing importance as a plant pathogen. For instance, E. cloacae has been associated with internal decay of onion (Schroeder et al., 2009; Bishop and Davis, 1990) and internal yellowing disease of papaya (Nishijima et al., 1987). Moreover, E. cloacae and other species of this complex are reported as pathogenic in mulberry in China (Wang et al., 2010), dragon fruit in Malaysia (Masyahit et al., 2009), macadamia in Hawaii (Nishijima et al., 2007), lucerne seeds in China (Zhang and Nan, 2013), odontioda orchids in Japan (Takahashi et al., 1997) and cassava in Venezuela (Santana et al., 2012). Among others, the main symptoms observed in these plants are wilted leaves that turned dark brown, and defoliated plants at late stage of the infection. 
Precise methods for identification and taxonomic classification are necessary, since its first description as E. cloacae underwent several taxonomic changes. The taxon $E$. cloacae was introduced in 1960 (Hormaeche and Edwards, 1960). Biochemical and molecular studies revealed a high degree of genomic heterogeneity among the species of Enterobacter. As a consequence, whole-genome DNA-DNA hybridizations and phenotypic characteristics led to the formulation of the taxon "E. cloacae complex" (also called "E. cloacae nomenspecies"), which comprises six species of Enterobacter (Mezzatesta et al., 2012). Phenotypic identification of species within the E.cloacae complex is difficult and not always reliable. Unambiguous identification of Enterobacter species can be achieved by DNA sequencing of the 16s rRNA gene, combined with genotyping based on $g y r \mathrm{~B}, h s p 60$ and $r p o \mathrm{~B}$ genes (Mezzatesta et al., 2012). Sequence information from $h s p 60$ and/or rpoB genes allows to assign isolates to one of the 12 genetic clusters, nine of which correspond to species, or to a $13^{\text {th }}$ less defined "sequence crowd" (Hoffmann and Roggenkamp, 2003). Higher resolution is possible by including more housekeeping genes in a multilocus sequence typing scheme (Paauw et al., 2008) or using phylogenomics (Liu et al., 2013).

The aim of this work was to characterize and identify the causative agents responsible for a new disease on chili pep- per (Capsicum annuum) that is affecting as many as $4 \%$ of seedlings grown in commercial greenhouses in northern, Mexico.

\section{Materials and Methods}

Isolation of plant-pathogenic bacteria from greenhousegrown pepper seedlings. In three consecutive years, 2013 to 2015, diseased seedlings of pepper were observed in two commercial greenhouses located on Delicias $\left(28^{\circ} 11^{\prime} 36^{\prime \prime}\right.$ $\mathrm{N}, 105^{\circ} 28^{\prime} 16^{\prime \prime} \mathrm{W}, 1171$ masl) and Meoqui $\left(28^{\circ} 16^{\prime} 04^{\prime \prime} \mathrm{N}\right.$, $105^{\circ} 33^{\prime} 37^{\prime \prime} \mathrm{W}, 1100$ masl) countries of Chihuahua State in Mexico. The concerned greenhouses displayed relatively warm $\left(36-38^{\circ} \mathrm{C}\right)$ and humid $(80-90 \% \mathrm{RH})$ conditions, while seedlings remained healthy in other greenhouses with lower RH. Symptoms were small necrotic lesions on leaves and brown necrosis at margins tips (Fig. 1). Assuming that the disease could be caused by bacteria, they were isolated from leaves of diseased seedlings of Jalapeño chili pepper cultivars (cvs.) Imperial, Perfecto, Tula and Maraja; Anaheim chili pepper cvs. Maverick and Cayenne; and a commercial hybrid (Table 1).

Leaves of symptomatic seedlings were collected in the greenhouse, then they were rinsed with sterile distilled water (SDW), disinfested with $0.3 \%$ sodium hypochlorite for
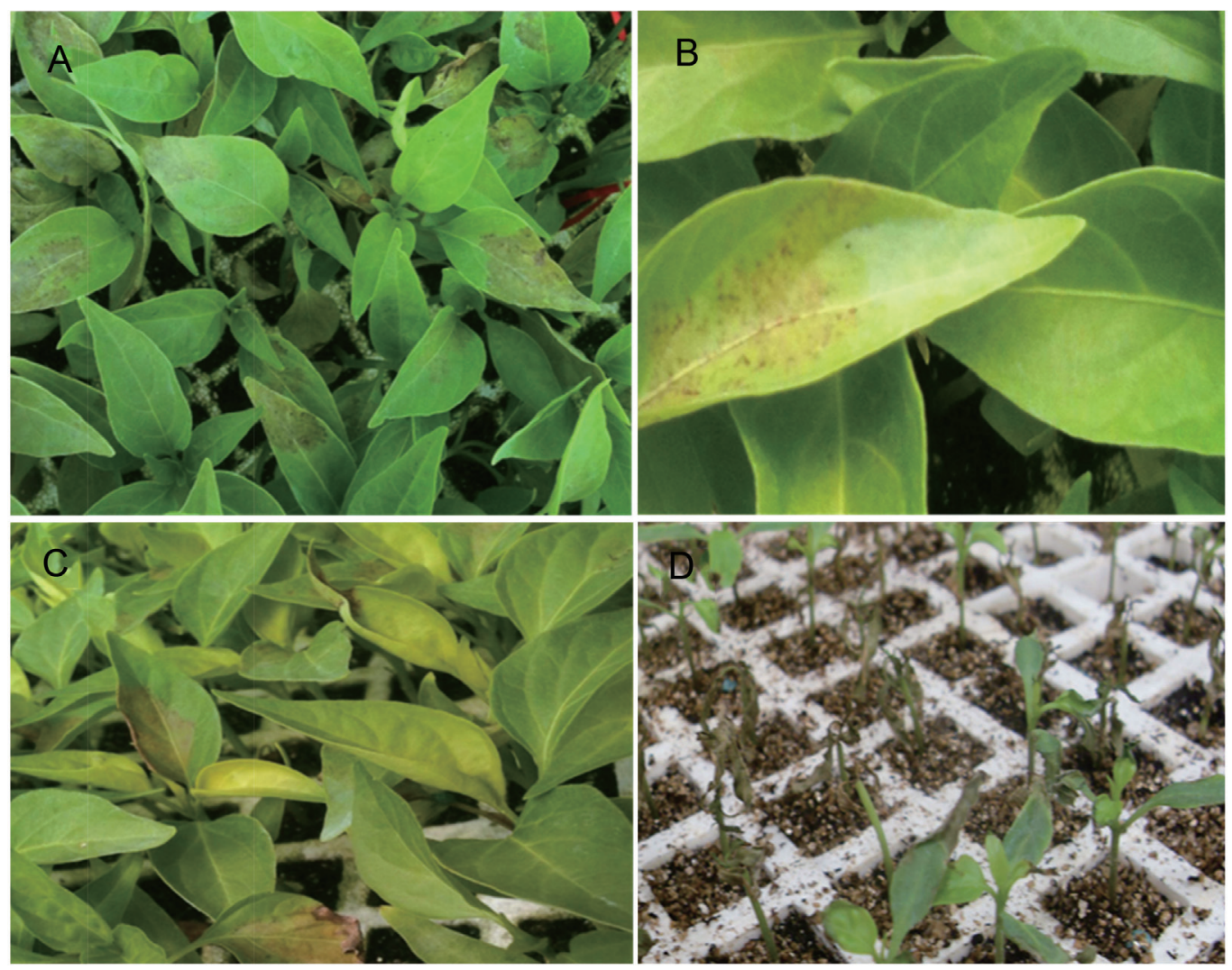

Fig. 1. Symptoms observed in chili (Capsicum annuum L.) pepper during seedlings production in commercial greenhouses in Mexico. (A) Initial symptoms in jalapeño pepper seedlings showing water-soaked in the middle of the leaves. (B) Chili pepper leaves with irregular brown spots and slightly yellowing. (C) Yellowing on the leaves with darkening in the affected area, apical necrosis is observed in some leaves. (D) Eventually, seedlings got completely defoliated after 60 days. 
Table 1. Bacterial strains isolated of Jalapeño, Anaheim and hybrid pepper (Capsicum annuum L.) seedling leaves from 35 days-old (10-18 cm high) planted in greenhouses during 2013-2015 in Chihuahua, México

\begin{tabular}{|c|c|c|c|}
\hline Strain number & Symptoms description & Type/Variety & $\begin{array}{c}\text { Procedence/ } \\
\text { (collection date) }\end{array}$ \\
\hline GAQ 120 & $\begin{array}{l}\text { Initial symptom: light brown random spots. } \\
\text { Eventually the seedling was defoliated. }\end{array}$ & Jalapeño/Perfecto & Meoqui/Mar 10th, 2015 \\
\hline GAQ 121 & $\begin{array}{l}\text { Initial symptom: light brown random spots (lesions). } \\
\text { Eventually the seedling was defoliated. }\end{array}$ & Jalapeño/Perfecto & Meoqui/Mar 10th, 2015 \\
\hline GAQ 126 & $\begin{array}{l}\text { Initial symptom: light brown random spots. } \\
\text { Eventually the seedling was defoliated. }\end{array}$ & Jalapeño/Imperial & Meoqui/Mar 11th, 2015 \\
\hline GAQ 127 & $\begin{array}{l}\text { Initial symptom: light brown random spots. } \\
\text { Eventually the seedling was defoliated. }\end{array}$ & Anaheim/Cayene & Delicias/Mar 9th, 2015 \\
\hline GAQ 128 & $\begin{array}{l}\text { Thin leaf tissue within the dark spot with black halo. } \\
\text { The spot did not respect veins of the leaf. }\end{array}$ & Anaheim/Maverick & Meoqui/Mar 14th, 2014 \\
\hline GAQ 129 & Thin leaf tissue within the dark spot. & Anaheim/Maverick & Meoqui/Mar 14th, 2014 \\
\hline GAQ 130 & $\begin{array}{l}\text { Grey light big spot covering almost half leaf, the spot did not } \\
\text { respect veins of the leaf. Irregular halo, chlorotic apex }\end{array}$ & Anaheim/Maverick & Meoqui/Mar 14th, 2014 \\
\hline GAQ 132 & Charred appearance leaf apex & Anaheim/Maverick & Meoqui/Mar 14th, 2014 \\
\hline GAQ 134 & Charred appearance leaf apex & Jalapeño/Marajá & Meoqui/Apr 10th, 2014 \\
\hline GAQ 135 & Charred appearance leaf apex & Jalapeño/Marajá & Meoqui/Apr 10th 2014 \\
\hline GAQ 136 & Apex and base of leaf light brown both had thin tissue & hybrid 5807 & Meoqui/Apr 10th, 2014 \\
\hline GAQ 137 & Charred appearance leaf apex & Jalapeño/Tula & Meoqui/2013 \\
\hline GAQ 138 & Charred appearance leaf apex & Jalapeño/Tula & Meoqui/2013 \\
\hline GAQ 140 & Charred appearance leaf apex & Jalapeño/Tula & Meoqui/2013 \\
\hline
\end{tabular}

$30 \mathrm{~s}$ and rinsed with SDW three times. Then leaves were drained and dried before aseptically sectioning. Small $(3 \times$ $3 \mathrm{~mm}$ ) leaf sections were then excised from the edge of the diseased tissue and macerated in $3 \mathrm{ml}$ of SDW for $90 \mathrm{~s}$ in a sterile mortar. The suspensions were streaked onto nutrient agar (NA) plates and incubated at $30^{\circ} \mathrm{C}$ for $24-48 \mathrm{~h}$. Single colonies were isolated and re-streaked at least twice to purify the bacterial strains. Isolated bacteria were identified using API 20E strips and were stored in $15 \%$ glycerol at $-80^{\circ} \mathrm{C}$ for long-term conservation.

Pathogenicity tests and re-isolation of bacteria upon seedlings inoculation. In 2015, different isolates were activated on Nutrient Agar (NA) medium and keep at $30^{\circ} \mathrm{C}$ for $48 \mathrm{~h}$. Plate-grown bacteria were resuspended in $30 \mathrm{ml}$ of SDW and adjusted to an optical density (OD) of 0.2 at $\mathrm{A}_{600}$, corresponding to approximately $10^{7}$ colony-forming units (CFU) per milliliter. As control, SDW was used.

Pathogenicity tests were performed on 50 day-old healthy seedlings, with four to six leaves, approximately $15 \mathrm{~cm}$ tall at the time of inoculation. Fourteen isolates were inoculated into Jalapeño pepper seedlings of the varieties Autlan and Rio grande, and Anaheim pepper seedlings of the variety Maverick.
Three different inoculation methods were evaluated. In the first one, three leaves of a seedling were puncturewounded with a hypodermic needle, followed by pipetteinoculation of $4 \mu \mathrm{l}$ of the bacterial suspension onto the wound. In the second one, the bacterial suspension was sprayed on the leaves until they were uniformly wet. In the third one, the bacterial suspension was injected with a needle-less 1-ml syringe, pressing the syringe on the lower side of three leaves per seedling. Four seedlings were inoculated per bacterial strain and SDW treatment controls, and each experiment was conducted two times.

Inoculated seedlings were held in polyethylene moist chambers within the greenhouse at $37^{\circ} \mathrm{C}$ and 80 to $90 \%$ relative humidity $(\mathrm{RH})$ and seedlings were watered daily. Following inoculation, seedlings were monitored to observe symptom development, such as dark spots with brown necrosis at the margins and tips of the leaves. Seedlings were maintained in the moist chambers until they were completely defoliated, as it had occurred in natural conditions. For re-isolation of the strains, symptomatic leaf tissue of inoculated seedlings was treated as described above. Re-isolated bacteria were identified by morphological characteristics and by using API 20E strips (Table 2). This identification allowed to know the re-isolated bacteria 
Table 2. Physiological and biochemical characteristics of the Enterobacter cloacae strains

\begin{tabular}{|c|c|c|c|c|c|}
\hline Characteristic & $\begin{array}{c}\text { Isolates from } \\
2013^{\mathrm{a}} \\
\end{array}$ & $\begin{array}{c}\text { Isolates from } \\
2015^{\mathrm{b}}\end{array}$ & $\operatorname{ATCC~} 13047^{c}$ & E. cloacae $^{\mathrm{d}}$ & $\begin{array}{c}\text { E. cloacae pathogenic } \\
\text { to cassava }^{\mathrm{e}}\end{array}$ \\
\hline Gram staining & - & - & - & - & - \\
\hline Rod shaped cell morphology & + & + & + & + & + \\
\hline \multicolumn{6}{|l|}{ Enzymatic activities: } \\
\hline$\beta$ galactosidase & + & + & + & & \\
\hline Arginine dehydrolase & + & + & + & + & + \\
\hline Lysine decarboxylase & - & - & - & - & - \\
\hline Ornithine decarboxylase & + & + & + & + & + \\
\hline Citrate utilization & + & + & + & + & + \\
\hline Hydrogen sulfide & - & - & - & - & - \\
\hline Urease & - & - & - & variable, or weak + & - \\
\hline Tryptophan deaminase & - & - & - & & - \\
\hline Indol & - & - & - & - & - \\
\hline Voges-Proskauer & + & + & + & + & + \\
\hline Gelatin liquefaction & - & - & - & & \\
\hline \multicolumn{6}{|l|}{ Acid production from: } \\
\hline D-Glucose & weak & + & + & + & + \\
\hline Mannitol & + & + & + & + & + \\
\hline Inositol & - & - & - & {$[-]$} & - \\
\hline D-Sorbitol & + & + & + & + & + \\
\hline L-Rhamnose & + & + & + & + & + one strain was - \\
\hline Sucrose & + & + & + & & \\
\hline D-Melibiose & + & + & + & + & + \\
\hline L-Arabinose & + & + & + & + & + \\
\hline \multicolumn{6}{|l|}{ Other tests: } \\
\hline D-Adonitol & - & & - & {$[-]$} & \\
\hline D-Mannose & + & & + & + & \\
\hline Salicine & + & & + & {$[+]$} & \\
\hline D-Cellobiose & + & & + & + & \\
\hline D-Maltose & + & & + & + & \\
\hline D-Lactose & weak & & - & + slow acid production & \\
\hline Raffinose & + & & + & + & \\
\hline Glycerol & - & & $\mathrm{d}$ & $\mathrm{D}$ & \\
\hline Esculin & - & & $\mathrm{d}$ & $\mathrm{D}$ & \\
\hline D-Arabitol & - & & - & - & \\
\hline
\end{tabular}

${ }^{a}$ Three isolates from 2013, analyzed by API 20E and API 50CH.

${ }^{b}$ Four isolates from 2015, analyzed by API 20E.

${ }^{\mathrm{c}-\mathrm{e}}$ Used reference strains; ${ }^{\mathrm{C}}$ E. cloacae ATCC 13047; ${ }^{\mathrm{d}}$ Data for E. cloacae from Bergey's manual (Bergey and Holt, 1994) and MacFaddin (2003);

'Data for E. cloacae pathogenic in cassava (Santana et al., 2012).

are identical to the original, thus fulfilling Koch's postulates.

Physiological and biochemical characterization. Reisolated bacteria from 2013, 2014 and 2015 were grown on NA plates at $30^{\circ} \mathrm{C}$ for 24 to $48 \mathrm{~h}$. Selected bacterial cultures were used for the biochemical tests. Gram staining was performed and cell morphology was investigated by microscopic examination. Biochemical identification was conducted using API 20E and API 50CH strips (BioMerieux Inc., Durham, NC, USA), according to the manufacturer's instructions.

Carbon substrate utilization was assessed using the Bio$\log ^{\circledR}$ system (Biolog Inc., Hayward CA, USA). Bacterial suspensions were inoculated into the GEN III Microplate ${ }^{\circledR}$ (Biolog Inc.) and incubated according to the manufacturer's instructions. The color reaction indicating utilization of 
Table 3. Carbon substrate utilization profile of the isolates from 2014

\begin{tabular}{|c|c|c|}
\hline Carbon source & Isolates from 2014 & E. cloacae $^{\mathrm{a}}$ \\
\hline Dextrin & + & \\
\hline D-Maltose & + & + \\
\hline D-Trehalose & borderline & + \\
\hline D-Cellobiose & + & + \\
\hline Gentiobiose & + & \\
\hline Sucrose & + & + \\
\hline D-Turanose & - & \\
\hline D-Raffinose & + & + \\
\hline$\alpha$-D-Lactose & + & + \\
\hline D-Melibiose & + & + \\
\hline D-Glucose & + & + \\
\hline D-Mannose & + & + \\
\hline D-Sorbitol & + & + \\
\hline D-Mannitol & borderline & + \\
\hline Gelatin & - & - \\
\hline Glycyl-L-proline & + & \\
\hline L-Alanine & + & \\
\hline L-Arginine & borderline & \\
\hline L-Aspartic acid & + & \\
\hline L-Glutamic acid & + & \\
\hline L-Histidine & + & \\
\hline L-Pyroglutamic acid & borderline & \\
\hline L-Serine & + & \\
\hline Pectin & + & \\
\hline D-Galacturonic acid & + & \\
\hline
\end{tabular}

${ }^{a}$ Data for E. cloacae from Bergey's manual (Bergey and Holt, 1994) and MacFaddin (2003).

each carbon substrate was determined visually and results were analyzed using the Biolog ${ }^{\circledR}$ database (http://www.biolog.com). A taxon was identified when the similarity index (SIM) was $>0.5$.
Molecular biological techniques. Genomic DNA was extracted by a modified hexadecyl trimethyl ammonium bromide (CTAB) method (Wang et al., 2010). One loop of $48 \mathrm{~h}$-old bacterial culture grown on NA plates were lysed. The lysis solution consisting of $600 \mu 1$ of $\mathrm{CTAB} / \mathrm{NaCl}$ ( $10 \%$ CTAB [Sigma-Aldrich, MO, USA] in $0.7 \mathrm{M} \mathrm{NaCl}$ ) at $65^{\circ} \mathrm{C}$ for $40 \mathrm{~min}$. Proteins were removed by extraction using chloroform/isoamyl alcohol (24:1) and phenol/chloroform/isoamyl alcohol (25:24:1). DNA was recovered by isopropanol precipitation and washed with $70 \%$ ethanol. The pellet was resuspended in $50 \mu 1$ of ultrapure water (Invitrogen, Carlsbad, CA, USA) and stored at $4^{\circ} \mathrm{C}$. DNA concentration and quality was measured using a spectrophotometer NanoDrop 2000C (Thermo Fisher Scientific Inc., Waltham, MA, USA).

For molecular diagnosis, an internal portion of the $16 \mathrm{~S}$ rRNA gene was amplified by polymerase chain reaction (PCR) with 8F/1492R and sequenced using U514F/800R primers (Li et al., 2010). In addition, two housekeeping genes, $h s p 60$ and rpoB, were analyzed by PCR and DNA sequencing, they showed to be polymorphic among Enterobacter isolates (Hoffmann and Roggenkamp, 2003; Miyoshi-Akiyama et al., 2013) (Table 4). Amplification reactions were carried out in a volume of $25 \mu$, started after a preheating time of $4 \mathrm{~min}$ at $95^{\circ} \mathrm{C}$. Samples for $16 \mathrm{~S}$ rRNA gene were subjected to 35 cycles of 2 min denaturation at $95^{\circ} \mathrm{C}, 1 \mathrm{~min}$ annealing at $56^{\circ} \mathrm{C}$, and $1.3 \mathrm{~min}$ of extension at $72^{\circ} \mathrm{C}$. Cycling was completed by a final elongation step of $5 \mathrm{~min}$ at $72^{\circ} \mathrm{C}$. Amplification conditions for $h s p 60$ and rpoB genes were 30 cycles of $30 \mathrm{~s}$ denaturation at $95^{\circ} \mathrm{C}$, $30 \mathrm{~s}$ annealing at $57.5^{\circ} \mathrm{C}$, and $3 \mathrm{~min}$ of extension at $72^{\circ} \mathrm{C}$. Final elongation was at $72^{\circ} \mathrm{C}$ for $15 \mathrm{~min}$.

DNA amplicons was checked by gel electrophoresis at $100 \mathrm{~V}$ for $40 \mathrm{~min}$ on a $1.5 \%$ agarose gel. PCR products remained were sequenced using a commercial service

Table 4. PCR primers used in this study

\begin{tabular}{|c|c|c|c|c|}
\hline PCR assay & PCR primer & Primer sequence & $\begin{array}{l}\text { Amplicon size } \\
(\mathrm{bp})^{\mathrm{a}}\end{array}$ & Reference \\
\hline \multirow[t]{2}{*}{$16 \mathrm{~S}$} & $8 \mathrm{~F}$ & 5'-AGAGTTTGATCATGGCTCAG & 1507 & Li et al., 2010 \\
\hline & $1492 \mathrm{R}$ & 5'-TACGGYTACCTTGTTACGACTT & & \\
\hline \multirow[t]{2}{*}{ hsp60 } & Hsp60-F ${ }^{b}$ & 5'-GGTAGAAGAAGGCGTRGGTHGC & 342 & Hoffmann and \\
\hline & Hsp60-R $\mathrm{R}^{\mathrm{b}}$ & 5'-ATGCAYYTCGGTEGTGATCATCAG & & Roggenkamp, 2003 \\
\hline \multirow[t]{2}{*}{ rpoB } & RpoB-F $F^{b}$ & 5'-AACCARTTCCGCGTTGGMCTGG & 1090 & Hoffmann and \\
\hline & RpoB-R $\mathrm{R}^{\mathrm{b}}$ & 5'-CCTGDACMACACGYTCKGA & & Roggenkamp, 2003 \\
\hline rpoB & rpoB-f & 5'-AAAAACGTATTCGTAAGGATTTTGGTAA & 945 & Miyoshi-Akiyama et al., \\
\hline
\end{tabular}

${ }^{a}$ Amplicon sizes were calculated from the genome sequence of the E. cloacae type strain ATCC 13047 (GenBank accession number CP001918). ${ }^{b}$ Degenerate variants of the published primer sequences were used in order to accommodate observed sequence polymorphisms in the available genome sequences of Enterobacter species. 
(Beckman Coulter Genomics, Roissy, France). For species identification, DNA sequences were compared with the non-redundant (nr) and whole-genome shotgun contigs (wgs) databases at the National Center for Biotechnology Information (NCBI) using the BLASTN option with default parameters (http://blast.ncbi.nlm.nih.gov) (Altschul et al., 1990). The strain GAQ130 have been deposited at GenBank under accession numbers KX822725 (16S rRNA), KX822726 (hsp60), and KX822727 (rpoB) as representative sequences.

Bioinformatic analyses. Sequence comparisons were performed on the websites of the European Bioinformatics Institute (http://www.ebi.ac.uk/services). DNA sequences were aligned using the Needleman-Wunsch algorithm (Needleman and Wunsch, 1970). For multiple sequence alignments, the MUSCLE algorithm was used (Edgar, 2004).

The platform Phylogeny.fr was selected to perform the phylogenetic analyses (Dereeper et al., 2008). MUSCLE (v3.7; Mill Valley, CA, USA) configured for highest accuracy (MUSCLE with default settings) was used to align the sequences. Regions containing gaps or poorly aligned were deleted with Gblocks (v0.91b; Castresana Lab, Barcelona, Spain). The phylogenetic tree was rebuilt on the PhyML program (v3.0; Oregon University, USA) with maximum likelihood, assuming the number of invariant sites and 4 gamma-distributed rate categories, to account for rate heterogeneity across sites, the HKY85 substitution model was used. The gamma shape parameter was calculated from the data. Internal branch reliability was estimated by the aLRTtest (SH-Like). The phylogenetic tree graphic and edition was performed with TreeDyn (v198.3; Montpellier, France).

\section{Results}

Plant pathogenic bacteria. Symptoms similar to those that had initially been observed in greenhouses appeared within four to 23 days after inoculation. No symptoms were observed on control plants that had been inoculated with SDW.

All 14 tested isolates were pathogenic to chili pepper seedlings. Inoculated seedlings exhibited irregular small spots on leaves. Later, these spots became necrotic with a chlorotic halo. Brown necrosis at margins tips was also observed. Finally, the seedlings were defoliated (Fig. 2). Control seedlings remained healthy. Bacterial strains were re-isolated from symptomatic inoculated seedlings. Our experiments represent a completion of the steps of Koch's postulates, demonstrating that E. cloacae is the causal agent of the new disease on chili pepper.

Physiological and biochemical characterization of bacteria isolated from pepper seedlings. The isolates formed creamy colonies on NA plates. Bacterial cells were rodshaped. Biochemical characteristics of three selected strains from 2013, four strains from 2014 and four strains from 2015 were evaluated using the API 20E and API 50CH systems and are summarized in Table 2. Comparison with published profiles and the E. cloacae ATCC 13047 reference strain suggested that the pepper-pathogenic bacteria belong to the E. cloacae. Identical taxonomic assignments were obtained with API $20 \mathrm{E}$ and API $50 \mathrm{CH}$ systems. The same results were observed with the inoculated and reisolated strains, suggesting that the strains were identical.

Carbon substrate utilization profiles were obtained using the Biolog system ${ }^{\circledR}$ (Biolog Inc.). Bacterial isolates from 2014 were tested and shown to be able to utilize 69 carbon sources (Table 3). A comparison with data from Bergey's manual (Bergey and Holt, 1994) and MacFaddin (2003) confirmed that the strains in study belonging to the E. cloa-
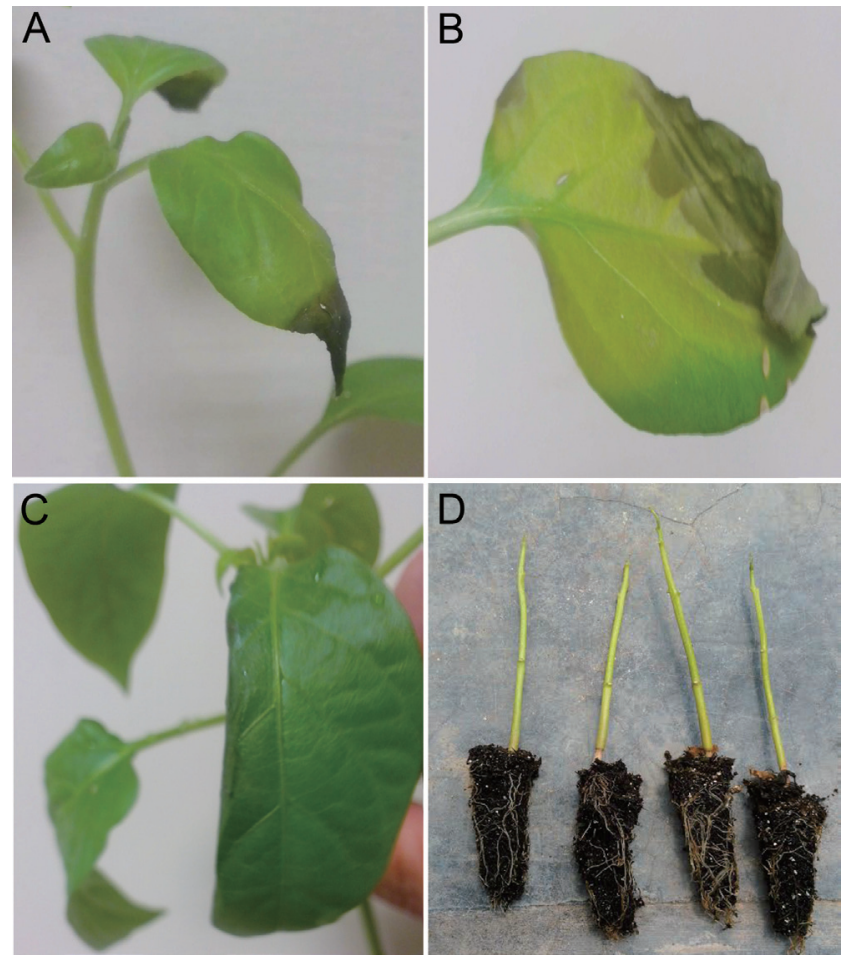

Fig. 2. Pathogenicity test in healthy jalapeño pepper seedlings from 50 days-old. (A) Apical necrosis observed in jalapeño pepper, 23 days after inoculation by injection method. (B) Foliar water-soaked necrosis with chlorotic halo. (C) Reduction on the foliar lamina. (D) Defoliated seedlings from 90 days-old. 


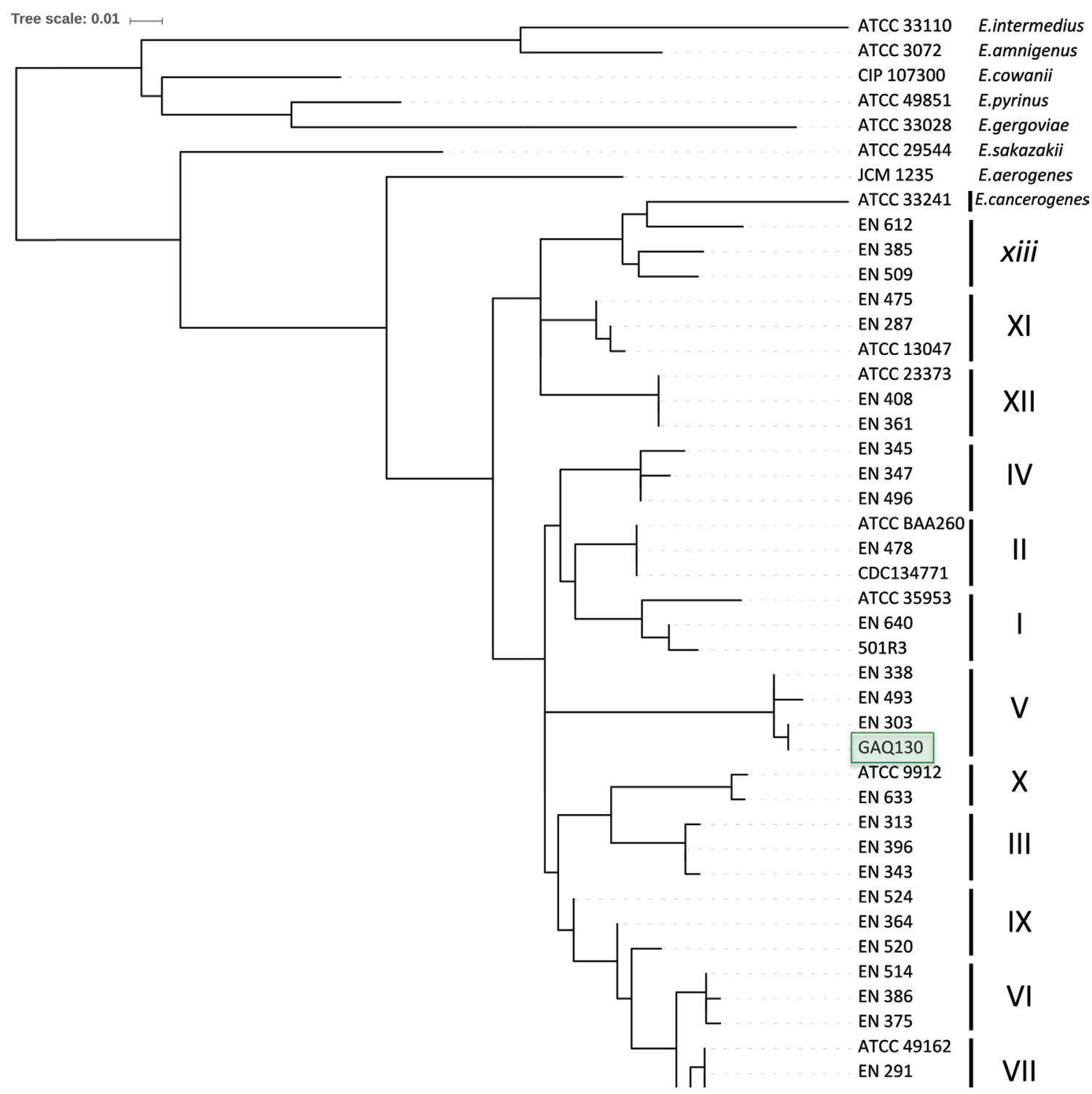

Fig. 3. Neighbor-joining tree after analyzing 264 nucleotides of the hsp60 gene 429 of the 14 isolates and reference strains of the genus $E$. cloacae from Hoffmann and Roggenkamp (2003).

cae. Based on the calculated similarity index (0.624) our isolates were identified as E. cloacae subsp. dissolvens.

Molecular identification of bacteria isolated from pepper seedlings. To further support the assignment of the pepper-pathogenic bacteria to the E. cloacae, portions of the 16S rRNA genes were amplified by PCR and sequenced. The obtained 16S rRNA gene fragments were identical to portions of the $16 \mathrm{~S}$ rRNA genes of several E. cloacae strains (e.g., GenBank accession numbers KT328458, KR061390, KF516245, CP006580).

To further refine the assignment of the pepper-pathogenic bacteria to distinct clades within the E. cloacae complex, portions of two housekeeping genes, $h s p 60$ and $r p o \mathrm{~B}$, were PCR amplified and sequenced. A phylogenetic tree based on 264-bp fragments of the $h s p 60$ gene showed that most isolates cluster with strains from the E. cloacae Cluster V (Hoffmann and Roggenkamp, 2003) (Fig. 3). Sequences of our isolates had $99 \%$ identity ( 1 mismatch) to sequences from E. cloacae strains P101 and EcWSU1 (accession numbers CP006580 and CP002886). A comparison with the $h s p 60$ fragments used by others revealed that our sequences were $100 \%$ identical to E. cloacae strain EN_303 (accession number AJ543775; Fig. 3). The phylogenetic tree based on a 545-bp portion of the rpoB gene was concordant with the $h s p 60$-derived tree, assigning the strains 


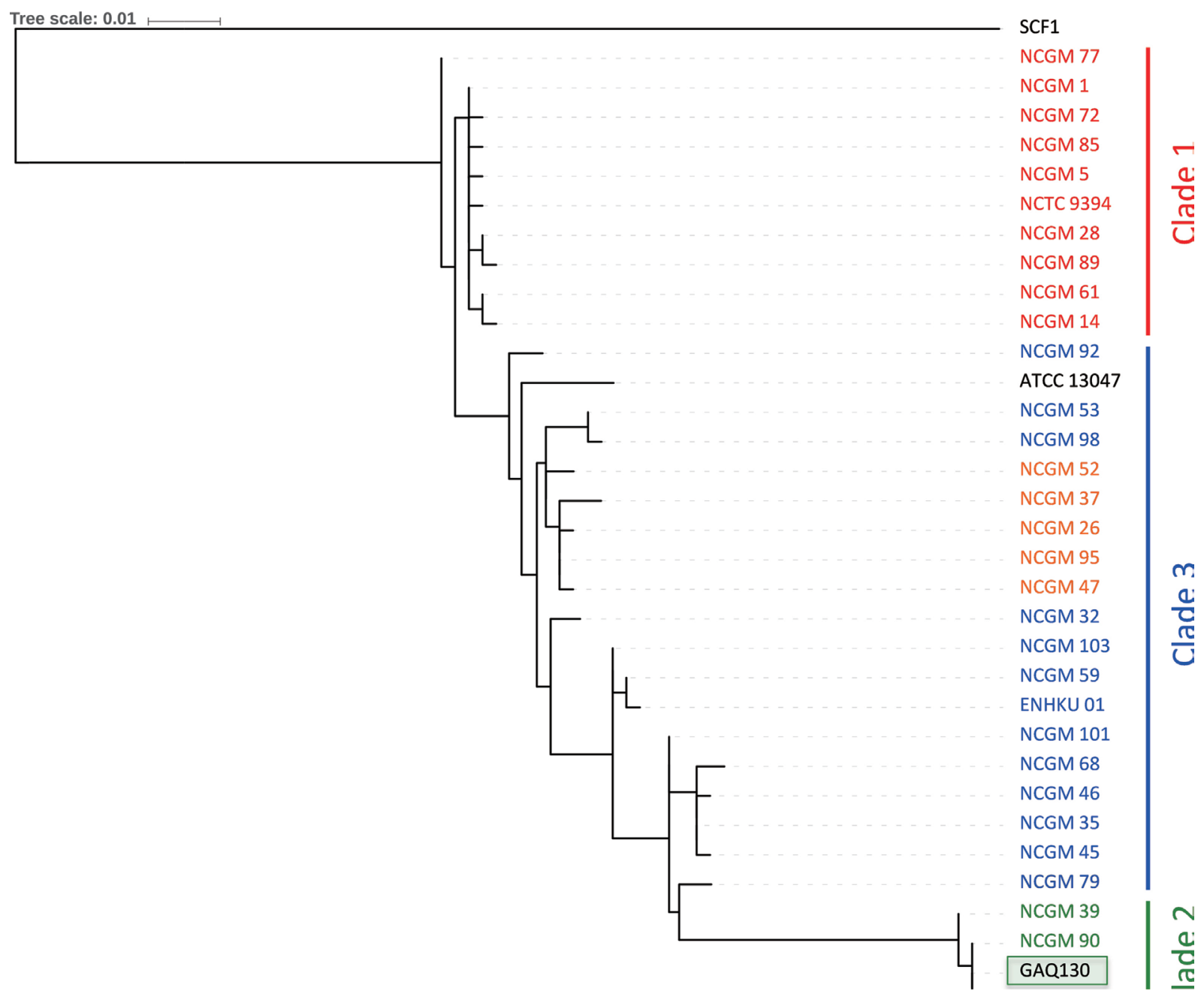

Fig. 4. Neighbor-joining tree after analyzing 545 nucleotides of the rpoB gene and strains of the genus E. cloacae from Miyoshi-Akiyama et al (2013).

to the E. cloacae (Fig. 4). All strains with at least 99\% identity to the $r p o \mathrm{~B}$ gene belonged to clade 2 according to Miyoshi-Akiyama et al. (2013).

\section{Discussion}

In this study, we describe a new disease on chili pepper seedlings caused by bacteria of the E. cloacae. Biochemical, physiological and molecular analyses were performed for 14 bacterial isolates and re-isolated bacteria upon artificial infection, thus fulfilling Koch's postulates. Compared to the Biolog system ${ }^{\circledR}$ (Biolog Inc.) with DNA-based methods, the latter showed to be more robust, reliable and resolutive for determination of the taxonomic position of the isolates in study. Yet, sequence information from the 16S rRNA gene alone was not conclusive. It did not allow discrimination among some of the Enterobacter species. However, the inclusion of sequence information from the hsp60 gene resulted in an accurate identification of the $E$. cloacae isolates, as reported by Hoffmann and Roggenkamp (2003) and Paauw et al (2008). Additionally, a partial rpo $\mathrm{B}$ sequence revealed genetic differences between the different isolates and allowed them to be compared with a large set of isolates, in agreement with a previous report that this gene provides good phylogenetic resolution (Case et al., 2007). Thus, sequences from rpoB and $h s p 60$ allow to accurately assign the isolates as E. cloacae subsp. dissolvens.

Bacteria of the genus Enterobacter, including members of the E. cloacae complex are adapted to survive and proliferate in diverse environments (Sanders and Sanders, 1997). Even if the E. cloacae is recognized mainly as causing harmful diseases affecting humans (Mezzatesta et al., 2012), it has also an important role as a causal agent of several plant diseases. Indeed, since 1922, E. cloacae has been repeatedly reported to cause diseases on a surprisingly wide 
variety of plants, such diverse as maize (Rosen, 1922), elm tree (Carter, 1945; Murdoch and Campana, 1983), coconut (George et al., 1976), onion (Cother and Dowling, 1986; Bishop and Davis, 1990; Schroeder et al., 2010), papaya (Nishijima et al., 1987), orchid (Takahashi et al., 1997), macadamia (Nishijima et al., 2007), dragon fruit (Masyahit et al., 2009), and mulberry (Wang et al., 2010).

Bacteria of the genera Enterobacter may become an opportunistic pathogen when changes in host physiology occurs related with high temperature (Cother and Dowling, 1986; Sanders and Sanders, 1997). Some reports mention that E. cloacae can be present in symptomless kernels (Nishijima et al., 2007), thus the emergence of an infection can be latent until environmental conditions are favorable for the onset of the disease. For example, a previous study reported an association of diseased onion plants in the field with a period of extreme heat $\left(40-45^{\circ} \mathrm{C}\right)$ (Bishop and Davis, 1990). This association has also been reported for mung bean sprouts (Wick et al., 1987) and for internal yellowing in papayas (Nishijima et al., 1987). In this study, we similarly observed that certain abiotic conditions provoked the production of symptoms. The disease caused by E. cloacae was severe at $38^{\circ} \mathrm{C}$ and $80 \% \mathrm{RH}$, whereas no symptoms were observed at $25^{\circ} \mathrm{C}$ and $30 \%$ of RH. In a preliminary field survey conducted in Mexican chili pepper fields to identify the E. cloacae symptoms on plants, no symptoms were observed on plants perhaps due to the relatively low humidity in this area of approximately 20 to $30 \%$. It is still unknown how the chili pepper seedlings became infected with E. cloacae. More research is needed to understand the epidemiology of this new disease and to develop management strategies to reduce its expansion.

\section{Acknowledgments}

Research was supported by the Secretaría de Educación Pública (SEP) Mexico under the PRODEP grant UACH PTC 305. Work in RK's laboratory was supported by IRD.

\section{Conflict of Interest}

The authors declare no conflict of interest.

\section{References}

Altschul, S. F., Gish, W., Miller, W., Myers, E. W. and Lipman, D. J. 1990. Basic local alignment search tool. J. Mol. Biol. 215:403-410.

Bergey, D. H. and Holt, J. G. 1994. Bergey's manual of determinative bacteriology. Wilkins and Wilkins, Baltimore, USA.

Bishop, A. L. and Davis, R. M. 1990. Internal decay of onions caused by Enterobacter cloacae. Plant Dis. 74:692-694.

Carter, J. C. 1945. Wetwood of elms. Ill. Nat. Hist. Surv. Bull. 23:407-448.

Case, R. J., Boucher, Y., Dahllöf, I., Holmström, C., Doolittle, W. F. and Kjelleberg, S. 2007. Use of 16S rRNA and rpoB genes as molecular markers for microbial ecology studies. Appl. Environ. Microbiol. 73:278-288.

Cother, E. J. and Dowling, V. 1986. Bacteria associated with internal breakdown of onion bulbs and their possible role in disease expression. Plant Pathol. 35:329-336.

Dalben, M., Varkulja, G., Basso, M., Krebs, V. L., Gibelli, M. A., van der Heijden, I., Rossi, F., Duboc, G., Levin, A. S. and Costa, S. F. 2008. Investigation of an outbreak of Enterobacter cloacae in a neonatal unit and review of the literature. $J$. Hosp. Infect. 70:7-14.

Davin-Regli, A. and Pagès, J. M. 2015. Enterobacter aerogenes and Enterobacter cloacae; versatile bacterial pathogens confronting antibiotic treatment. Front. Microbiol. 6:392.

Dereeper, A., Guignon, V., Blanc, G., Audic, S., Buffet, S., Chevenet, F., Dufayard, J. F., Guindon, S., Lefort, V., Lescot, M., Claverie, J. M. and Gascuel, O. 2008. Phylogeny.fr: robust phylogenetic analysis for the non-specialist. Nucleic Acids Res. 36:465-469.

Edgar, R. C. 2004. MUSCLE: multiple sequence alignment with high accuracy and high throughput. Nucleic Acids Res. 32:1792-1797.

Fanaro, S., Chierici, R., Guerrini, P. and Vigi, V. 2003. Intestinal microflora in early infancy: composition and development. Acta Paediatr. 91:48-55.

George, M., Potty, V. P. and Jayasankar, N. P. 1976. Association of Enterobacter with coconut root (wilt) disease. Curr. Sci. 45:677-678.

Hormaeche, E. and Edwards, P. R. 1960. A proposed genus Enterobacter. Int. Bull. Bacteriol. Nomencl. Taxon. 10:71-74.

Hoffmann, H. and Roggenkamp, A. 2003. Population genetics of the nomenspecies Enterobacter cloacae. Appl. Environ. Microbiol. 69:5306-5318.

Li, D., Li, Z., Yu, J., Cao, N., Liu, R. and Yang, M. 2010. Characterization of bacterial community structure in a drinking water distribution system during an occurrence of red water. Appl. Environ. Microbiol. 76:7171-7180.

Liu, W. Y., Wong, C. F., Chung, K. M., Jiang, J. W. and Leung, F. C. 2013. Comparative genome analysis of Enterobacter cloacae. PLoS One 8:e74487.

MacFaddin, J. F. 2003. Biochemical tests for the identification of bacteria of clinical importance. Ed. Medica Panamericana, Buenos Aires, Argentina.

Masyahit, M., Sijam, K., Awang, Y. and Ghazali, M. 2009. First report on bacterial soft rot disease on dragon fruit (Hylocereus spp.) caused by Enterobacter cloacae in peninsular Malaysia. Int. J. Agric. Biol. 11:659-666.

Mezzatesta, M. L., Gona, F. and Stefani, S. 2012. Enterobacter cloacae complex: clinical impact and emerging antibiotic resistance. Future Microbiol. 7:887-902. 
Miyoshi-Akiyama, T., Hayakawa, K., Ohmagari, N., Shimojima, M. and Kirikae, T. 2013. Multilocus sequence typing (MLST) for characterization of Enterobacter cloacae. PLoS One 8:e66358.

Murdoch, C. W. and Campana, R. J. 1983. Bacteria species associated with wetwood of elm. Phytopathology 73:1270-1273.

Needleman, S. B. and Wunsch, C. D. 1970. A general method applicable to the search for similarities in the amino acid sequence of two proteins. J. Mol. Biol. 48:443-453.

Nishijima, K. A., Couey, H. M. and Alvarez, A. M. 1987. Internal yellowing, a bacterial disease of papaya fruits caused by Enterobacter cloacae. Plant Dis. 71:1029-1034.

Nishijima, K. A., Wall, M. M. and Siderhurst, M. S. 2007. Demonstrating pathogenicity of Enterobacter cloacae on macadamia and identifying associated volatiles of gray kernel of macadamia in Hawaii. Plant Dis. 91:1221-1228.

Paauw, A., Caspers, M. P. M., Schuren, F. H. J., Leverstein-van Hall, M. A., Delétoile, A., Montijn, R. C., Verhoef, J. and Fluit, A. C. 2008. Genomic diversity within the Enterobacter cloacae complex. PLoS One 3:e3018.

Rosen, H. R. 1922. The bacterial pathogen of corn stalk rot. Phytopathology 12:497-499.

Sanders, J. W. and Sanders, C. C. 1997. Enterobacter spp.: pathogens poised to flourish at the turn of the century. Clin. Microbiol. Rev. 10:220-241.

Santana, M. A., Rodriguez, M., Mathehus, J., Faks, J., Bocsanc- zy, A., Gerstl, A., Romay, G., Montilla, J., Fernánde, C. E., Moreno-Zambrano, N. and Marval, D. 2012. A new bacterial disease of cassava in Venezuela caused by Enterobacter cloacae. Int. J. Agric. Biol. 14:183-189.

Schroeder, B. K., Waters, T. D. and du Toit, L. J. 2010. Evaluation of onion cultivars for resistance to Enterobacter cloacae in storage. Plant Dis. 94:236-243.

Schroeder, B. K., DuToit, L. J. and Schwarts, H. F. 2009. First report of Enterobacter cloacae causing onion bulb rot in the Columbia Basin of Washington State. Plant Dis. 93:323.

Takahashi, Y., Takahashi, K., Sato, M., Watanabe, K. and Kawano, T. 1997. Bacterial leaf rot of Odontioda orchids caused by Enterobacter cloacae. Ann. Phytopathol. Soc. Jpn. 63:164169.

Wang, G. F., Xie, G. L., Zhu, B., Huang, J. S., Liu, B., Kawicha, P., Benyon, L. and Duan, Y. P. 2010. Identification and characterization of Enterobacter complex causing mulberry (Morus alba) wilt disease in China. Eur. J. Plant Pathol. 126:465478.

Wick, R. L., Rane, K. K. and Sutton, D. K. 1987. Mung bean sprout disease caused by Enterobacter cloacae. Phytopathology $77: 123$.

Zhang, Z. F. and Nan, Z. B. 2013. Occurrence of lucerne seedborne Enterobacter cloacae sprouts decay in Gansu Province of China. Eur. J. Plant Pathol. 135:5-9. 